\title{
Management of psoriasis through ayurveda: case study
}

\author{
Anshul $^{1}$, Rohilla Pooja ${ }^{2}$, Kumar Parvesh ${ }^{3}$ and Raheja Shipra ${ }^{4}$
}

Received: 18.04.2020

Revised: 08.05.2020

Accepted: 16.05.2020

\begin{abstract}
This case study intends to evaluate the efficacy of Vaman-Virechan in the management of recurrent psoriasis.A 38 year male presenting with psoriasis with mild arthritis was diagnosed as Ekkustha (kapha-pitta dominance) as per Ayurveda. Vaman-Virechana and Panchtiktaghrit gugglu were given to the patient. Symptoms were assessed with PASI at pre and post therapy along with 6 months follow up. Improvement was observed with PASI score (reduced from 37.7 to 8.7). During follow up period no recurrence observed. Ayurveda shodhan \& shaman therapy resulted in effective management of Psoriasis as assessed by validated scales.
\end{abstract}

Key Words: Ayurveda, Psoriasis, Panchtiktaghrit gugglu, vaman, virechana

\section{Introduction}

Psoriasis is a chronic, inflammatory, immunemediated proliferative, disfiguring and disabling disease for which there is no cure. In addition to the involvement of skin, inflammatory arthritis (psoriatic arthritis) may develop. Patients suffering from psoriasis are at higher risk of developing cardiovascular and other Non Communicable Diseases. Prevalence of psoriasis in countries vary between $0.09 \%$ and $11.4 \%$. Marked socioeconomic load is considered on an individual level because of lost opportunities in professional life and elevated economic burden for treatment expenses as per WHO (World Health Organization 2016). Methotrexate, corticosteroids etc. can be used for both skin and joint manifestations in conventional system of medicine, but their long-term use is hindered by safety concerns.(Gan, et al. 2013) Therefore, there is need to develop a management for psoriasis which can give benefit on a long run without any adverse effects. On the basis of sign \& symptoms like reduced sweating (Asweda), extended skin lesions (Mahavastu), scaling of skin similar to the scales of the fish (Matsya shakalopama), pink discoloration

\section{Author's Address}

${ }^{1}$ Department of Panchkarma GBAC ROHTAK

${ }^{2}$ Department of Dravyaguna, Shri Baba Mastnath Ayurvedic College, Rohtak

${ }^{3}$ Dept. Of Agadtantra, Gaur Brahman Ayurvedic College, Brahmanwas, Rohtak

${ }^{4}$ Dept. of Panchkarma. M.O.Shatayu Ayurveda, Bangalore

E-mail.: dr.poojarohilla06@gmail.com
(Aruna varna), blackening of the part (Krishnavarna) etc, this disease can be correlated with Ekkustha (Shastri, 2011) In present case study there is kapha-pitta dominancy with involvement of tridosha. Therefore for this study, vaman and virechana as samshodhan (bio-cleansing therapy) and Panchtiktaghrit gugglu was planned as described in treatment of kustha (Shastri, 2007).

\section{Material and Methods}

In the present case, a 37 year old male, bus conductor came to the Department of Pañchkarma, Rishikul Campus, Haridwar, Uttrakhand, India with a history of red and white lesions (scaly thickened skin) on whole body in patches with associated itching, burning and increasing size of patches from 18 years. He took various module of treatment but patient was reluctant, because remission of symptoms occurs after withdrawal of medicine so he approached Rishikul hospital for conservative treatment. Past history of patient included excessive fasting along with exertion before starting of symptoms initially. Symptoms especially itching increases with cold wind, cloudy environment and winter season along with increase in stiffness of joints like knee, phalanges. Declaration of Helsinki was followed during case handling.

During Astavidha pariksha; Nadi ( pulse) was Vata-Kaphaja; Jihva ( tongue) was clear/uncoated; Mala ( stool) was Niram; Mutra (urine) was of light yellow coloured; Sabda(speech), Sparsa(touch), Drika(eyesight), Akriti were found

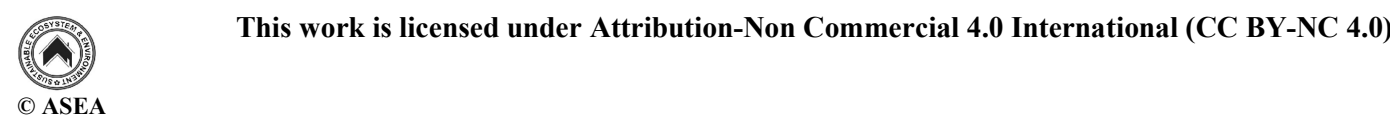

This work is licensed under Attribution-Non Commercial 4.0 International (CC BY-NC 4.0) 
normal. Prakriti ( constitution) of patient was kapha-pitta, Vikriti( pathogenesis) was VataKaphaj, Samhana( body composition): medium and Vyayam Shakti ( exercise capacity) was Pravar, Jarana Shakti( digestion capacity), Ahara Shakti, Satva, Satyama, Bala(strength) were found Pravar, Agni ( metabolism) was Vishamagni ( altered) during Dashvidha Pariksha. There was no history of streptococcal infection. During cardiovascular and respiratory system examination, findings were normal.

There were mild difficulties in movement of joints.

Criteria for assessment: Patient was assessed with Psoriasis Area and Severity Index (PASI) Score (British Association of Dermatologist n.d.) for the presenting symptoms (table1)

Morphology: Well defined, Dry and rough, raised, $\&$ light purple colored patches

Distribution - widely distributed

Pattern: scattered patches (Generalized)

No association of any other cutaneous disorders (alopecia aereata, halo navus, atopic dermatitis, malignant melanoma \& morphea)

Koebner's phenomenon- Present

Sensation - intact

Auspitz \& Candle grease Sign - positive.

Course: Slowly progressive
Pharmacological treatment: Vaman karma ( induced vomiting), virechana( $\sim$ purgation)

Trikatu Churna $3 \mathrm{gm}$ twice a day with lukewarm water given.

Ghritpana with panchtikta ghrita was given in increasing dose pattern for 7 days when symptoms of samayak snigdha appeared.

Vamana carried out with milk, Madanphalapippali, Vacca churn.

After regimen (sansarjana), Snehpana started again for Virechana procedure till proper snehpana features. Abhyanga (massage) and swedana for 3 days was carried out. Thereafter, Virechana drugs i.e. $100 \mathrm{ml}$ decoction of Triphala along with Trivrita Avaleha 60 gm was given.

Follow up and Outcomes: Before and after treatment grading of symptoms is shown in table 2.

After completion of Vaman- virechana, Panchtiktaghrit gugglu was given 2 TDS before meal for 1 month along with external application of Nimbadi Tail. Follow up was done after 6 months.

Adherence and tolerability of intervention was assessed by the patient. There was no adverse or unanticipated event during treatment. No diagnostic or other tests were performed after treatment.

PASI score - Before treatment- 37.7, After treatment -8.7

Table 1: Showing the pasi score calculation and grandings

\begin{tabular}{|c|c|c|c|c|}
\hline \multirow{2}{*}{\multicolumn{2}{|c|}{$\begin{array}{l}\text { Plaque characteristic } \\
\text { Erythema } \\
\text { Induration/ Thickness } \\
\text { Scaling } \\
\text { Lesion score sum (A) }\end{array}$}} & Lesion score & Percentage area affected & Area score \\
\hline & & $\begin{array}{l}\text { 0- None } \\
\text { 1-Slight } \\
\text { 2-Moderate } \\
\text { 3-Severe } \\
\text { 4- Very severe }\end{array}$ & $\begin{array}{l}\text { Area Score (B) } \\
\text { Degree of involvement } \\
\text { as a percentage for each body } \\
\text { region affected (score each } \\
\text { region in between } 0-6)\end{array}$ & $\begin{array}{l}0=0 \% \\
1=1 \%-9 \% \\
2=10 \%-29 \% \\
3=30 \%-49 \% \\
4=50 \%-69 \% \\
5=70 \%-89 \% \\
6=90 \%-100 \%\end{array}$ \\
\hline \multicolumn{5}{|c|}{$\begin{array}{l}\text { Multiply Lesion Score Sum (A) by Area Score (B), for each body region, to give } 4 \text { individual subtotals } \\
\text { (C). }\end{array}$} \\
\hline \multicolumn{2}{|l|}{ Subtotals (C) } & & & \\
\hline \multicolumn{5}{|c|}{$\begin{array}{l}\text { Multiply each of the Subtotals (C) by amount of body surface area represented by that region, i.e. } \mathrm{x} 0.1 \text { for head, } \mathrm{x} \\
0.2 \text { for upper body, } \mathrm{x} 0.3 \text { for trunk, and } \mathrm{x} 0.4 \text { for lower limbs }\end{array}$} \\
\hline $\begin{array}{l}\text { Body surface } \\
\text { area }\end{array}$ & $\mathrm{X} 0.1$ & $\mathrm{X} 0.2$ & $\mathrm{X} 0.3$ & X0.4 \\
\hline Totals (D) & & & & \\
\hline
\end{tabular}




\section{Results and Discussion}

Patient was having lower middle socioeconomic status. After 2 months of treatment, grading of scaling were changed from 3 to 0 and 1 and erythema grading to 1 according to body area which was major a change. $50 \%$ change in area score was observed in all areas after treatment. Burning and itching got relieved 100\%. Induration grading was not changed in head and lower limbs. Change in grading of other parts was from 2 to 1 and 3 to 2 which is negligible.

Area occupied by the patches got more than 50\% decreases. After treatment PASI score was significantly reduced from 37.7 to 8.7 . In the follow up of 6 months, patient has no recurrence of previous patches, also no new patches developed on body.This case report is significant as it is a severe psoriasis and the patient had tried all possible conventional treatment modalities with no relief in symptoms even with continuation of medicine. Severe burning, itching were prevalent and compromising quality of life.

This case report intended to check the efficacy of Vaman and Virechana as shodhan and panchtiktaghrit gugglu as shaman in management of severe Psoriasis. Methotrexate used as conventional treatment of psoriasis limits epithelial hyperplasia by inhibiting DNA synthesis. Also decreases the synthesis of a range of proinflammatory cytokines such as tumour necrosis factor $\alpha$ and interleukin-1(Czarnecka and Anna, 2014).

Shodhana procedure prevents the recurrence of doshas and same effect found in patient condition ${ }^{7}$.

Decrease in Erythrocyte Sedimentation Rate, Lowdensity lipoprotein cholesterol (LDL), total cholesterol, Blood urea nitrogen (BUL), total serum protein, serum Creatinine, plasma histamine and plasma adrenaline along with increase in highdensity lipoprotein cholesterol (HDL), Very Low Density Lipoproteins, and Immunoglobulin E level after 15 days of Vamana in healthy volunteers(Gupta et al. 2012) indicate towards the purification of Rakta which is basis for healthy skin. In a case control study on Psoriasis, evidence of electrolyte imbalance among psoriasis patients were found as an increase of electrolyte levels of sodium as compared to the controls(T et al. 2018). Increased sodium levels in the body cause raised sodium to potassium ratio, which leads to dry skin and mucosal membrane presenting as scaly patches on skin of psoriasis patients. Significant decrease in level of serum sodium was found after virechana. (Rais and Bhatted, 2013) Improvements found in study support this evidence.

Table 2: Showing gradings of symptoms before treatment (bt) and after treatment (at)

\begin{tabular}{|l|l|l|l|l|l|l|l|l|}
\hline $\begin{array}{l}\text { Plaque } \\
\text { characteristic }\end{array}$ & Head & \multicolumn{2}{l|}{ Upper body } & \multicolumn{2}{l|}{ Trunk } & \multicolumn{2}{l|}{ Lower limbs } \\
\hline & BT & AT & BT & AT & BT & AT & BT & AT \\
\hline Erythema & 3 & 1 & 2 & 1 & 3 & 1 & 3 & 1 \\
\hline $\begin{array}{l}\text { Induration/ } \\
\text { Thickness }\end{array}$ & 2 & 2 & 2 & 1 & 3 & 2 & 2 & 2 \\
\hline Scaling & 3 & 1 & 3 & 0 & 3 & 0 & 3 & 1 \\
\hline Area Score & 5 & 2 & 3 & 1 & 5 & 3 & 5 & 3 \\
\hline
\end{tabular}

Secondary, Pitta is site of agni and thus responsible for maintainance of all kriya ( $\sim$ catabolism anabolism process) and for glowing of skin chhaya. In Psoriasis, keratinocytes secrete inflammatory markers like interferons, cytokines(T et al. 2018). These markers can be considered vitiated pitta leading to psoriatic lesions. Considering pitta vitiation in this disease, virechana was planned as it is best in imbalanced pitta. Panchatikta Ghrita Guggulu have nutritive and Shodhan ( purifying) effect on all dhatus seen by effect on present disease in which all dhatus are involved in pathogenesis. Positive effect on osteoarthritis (Akhtar et al. 2010) supports its anti-inflammatory and nutritive activity.

Snehapana and shodhana are main line of treatment for kushta (Shastri, 2011). In Panchatikta ghrita guggul, action of Snehana is carried out by ghrit and Shodhana by tikta rasa. Action on psoriasis can also be understood according to properties of contents (Panchatikta drugs, ghee \& Guggul) used. Panchatikta drugs actions are as follows: 
Nimbin, Nimbidin from Nimb (Azadiracta indica) possesses anti-inflammatory activity. Berberin and tinosporin from Guduchi (Tinospora cordifolia) acts as anti-oxidant and immune-potentiating. Vascicinone from Vasa (Adhatoda vasica) has antihistaminic, anti-oxidant \& anti - inflammatory effect. Patol (Trichosanthas dioica) has antioxidant \& Nidigdhika (Solanum xanthocarpum) has anti-histaminic property. All these action support the action of tikta rasa (Shastri, 2009) i.e. Pitta shamak, vikrut meda upashoshan, vranashodhak (wound-purifier) and anti itching effect. (Lokhande et al. 2016)

Purana Guggulu (Commiphera mukul) has antiinflammatory and immunomodulatory action. (Akhtar et al. 2010). Lipophilic nature of Ghrita facilitates entry of drug in to cell via helping in ion transportation and thus helps in restoring the normal texture to skin. (Lokhande et al. 2016). Also because of Yogavahi property Ghrita is helpful in increasing bio-availability of other panchtikta drugs and gugglu (Gupta, 2011).

Two months treatment has prevented the severe psoriasis for longer duration without side effect which was not relieved by contemporary medicines. Severe psoriasis patient of Vata- kapha prakriti having symptoms of kapha-pitta predominance in psoriasis can be treated with Vaman-Virechana and panchtiktaghrit gugglu. Case should be postulated by diagnostic findings. Other parameters should be taken to assess before and after changes. The patient was exposed to vigorous treatment modalities, often exhaustive and prolonged inpatient stay were considered as the limitations of the study. In further studies, there is need to validate the findings with deeper insights. Forthcoming studies that integrate symptomatic findings after procedure with changes in metabolomic and genomic parameters may facilitates a broader system level understanding and mechanistic insights into these integrative practices that are employed to promote health and well being.

\section{Conclusion}

As in this case report, patient got significant relief, it may be concluded that Vaman-Virechana and panchtiktaghrit gugglu prove to be effective in the management of Psoriasis with mild arthritis by virtue of its Tridosha Shamaka property.
Randomised Clinical Trial needs to be conducted to validate result in larger sample which will generate evidence for support.

\section{Acknowledgement}

Special thanks to Dr. Bharat Krushna khuntia from Centre for Integrative Medicine and Research (CIMR), convergence block, All India Institute of Medical Sciences.

\section{References}

Akhtar, Babul, RajaRam Mahto, AR Dave, and VD Shukla. 2010. "Clinical Study on Sandhigata Vata w.s.r. to Osteoarthritis and Its Management by Panchatikta Ghrita Guggulu." AYU (An International Quarterly Journal of Research in Ayurveda) 31(1): 53

Shastri Ambikadatta (ed.) 2007. Bhaishajya Ratnavali of Shri Govind Das, Chaukhambha prakashan, Varansi.

Shashtri, Ambikadutta (ed.) 2011. Ayurveda-tattva-sandipika hindi commentary on Sushrut Samhita of Shushrut, Chaukhambha Sanskrit Sansthan, Varansi.

Gupta , Atrideva (ed.) 2011. Vidyotini hindi commentary on Astanghridyam of Vagbhatta, Chaukhambha prakashan, Varansi.pg 250.

British Association of Dermatologist. PSORIASIS AREA AND SEVERITY INDEX ( PASI) WORKSHEET Severity of Psoriatic Lesions Based on Area Coverage and Plaque Appearance . PASI Score $=$ : : 4.

Czarnecka-Operacz, Magdalena, and Anna SadowskaPrzytocka. 2014. The Possibilities and Principles of Methotrexate Treatment of Psoriasis - The Updated Knowledge. Postepy Dermatologii i Alergologii 31(6): 392-400.

Gan, Emily Yiping, Wei Sheng Chong, and Hong Liang Tey. 2013. Therapeutic Strategies in Psoriasis Patients with Psoriatic Arthritis: Focus on New Agents. BioDrugs 27(4): 359-73.

Gupta, Bharti, Sushil C. Mahapatra, Renu Makhija, Adarsh Kumar, Nikhil M. Jirankalgikar, Madan M. Padhi, Ramesh Babu Devalla 2012. Physiological and Biochemical Changes with Vamana Procedure. AYU (An International Quarterly Journal of Research in Ayurveda) 33(3): 348.

Lokhande, Smita, Swapnil Patil, and Satish Parshurami. 2016. "Efficacy of Panchatikta Ghrit Guggul in the Management of Mandal Kushtha With Special Reference To Psoriasis." International Journal of Research in Ayurveda \& Pharmacy 7(4): 94-96.

Shastri Pt.Kashinath , Grakhnath chaturvedi (ed.) 2009. Vidyotini hindi commentary on Charak Samhita of 


\section{Management of psoriasis through ayurveda}

Agnivesh vol-I, Chaukhambha Bharti Academy, Sudhakar T, Sabitha V, Raj Kumar G , Jhansi Rani C , Varansi.pg321. Pratyusha P , Bheem J and Venkataramana K 2018. Evaluation of Serum Electrolytes among Psoriasis Patients:

Shastri Pt.Kashinath , Grakhnath Chaturvedi (ed.) 2011. Vidyotini hindi commentary on Charak Samhita of Agnivesh vol-II, Chaukhambha Bharti Academy, Varansi. A Prospective Case-Control Study from Telangana, South India. Biochemistry \& Analytical Biochemistry 07(04): 14. DOI:10.4172/2161-1009.1000365

Rais, Adil, and Santoshkumar Bhatted. 2013. Clinical Study to Evaluate the Effect of Virechanakarma on Serum Electrolytes. AYU (An International Quarterly Journal of Research in Ayurveda) 34(4): 379.

World Health Organization. 2016. Global Report On. Global Report on Psoriasis 978: 1-26. http://www.who.int/about/licensing/copyright_form/index. html\%0Ahttp://www.who.int/about/licensing/. 